\title{
Çimentolu Macun Dolgunun Dayanım ve Mikroyapı Özellikleri; C-Sınıfı Uçucu Külün Etkisi
}

\section{Strength and Microstructure Properties of Cemented Paste Backfill; Effect of Class-C Fly Ash}

\author{
Bayram Erçıkdı ${ }^{*}$ (), Tekin Yılmaz ${ }^{1}(\mathbb{0}$ \\ ${ }^{1}$ Karadeniz Teknik Üniversitesi, Mühendislik Fakültesi, Maden Mühendisliği Bölümü, 61080, Trabzon, TÜRKIYE \\ Sorumlu Yazar / Corresponding Author*: bercikdi@ktu.edu.tr \\ Geliș Tarihi / Received: 02.04.2018 \\ Kabul Tarihi / Accepted: 25.09.2018 \\ DOI:10.21205/deufmd.2019216102 \\ Araștırma Makalesi/Research Article
}

Atıfșekli/How to cite: ERÇIKDI, B., YILMAZ, T. (2019). Çimentolu Macun Dolgunun Dayanım ve Mikroyapı Özellikleri; C-Sınıfi Uçucu Külün Etkisi. DEUFMD, 21(61), 15-23.

Öz

Bu çalışmada, sülfürlü atık yerine ağırlıkça \%5-15 oranında C-sınıfı uçucu kül (UK) ikamesinin çimentolu macun dolgunun (ÇMD) dayanım ve mikroyapı özelliklerine etkisi incelenmiştir. Bu kapsamda kontrol numuneleri \%8,5 bağlayıcı oranında, UK içeren dolgu numuneleri ise \%7,5 bağlayıcı oranında hazırlanmıştır. Bu numuneler, tek eksenli basınç dayanımı (TEBD) ve porozite (MIP) testlerine tabi tutulmuştur. Bulgular değerlendirildiğinde, UK içeren tüm ÇMD numunelerinin kontrol numunelerine klyasla 1,18-3,16 kat daha yüksek TEBD ürettiği gözlemlenmiştir. Dolgunun stabilite (TEBD $\geq 1,0 \mathrm{MPa})$ kriterini tüm numuneler sağlarken, tavan (zemin) tahkimatı (TEBD $\geq 5,0 \mathrm{MPa})$ kriterini sadece \%15 UK'lı numuneler sağlamıștır. Porozite (MIP) gelișimleri incelendiğinde, UK ikamesi numunelerin mikroyapı özelliklerini daha fazla iyileștirmiștir. Elde edilen sonuçlardan, C-sınıfı UK kullanımının ÇMD’nin dayanım, duraylılık ve mikroyapı özelliklerinin iyileştirilmesinde oldukça faydalı olduğu sonucuna varılmıştır.

Anahtar Kelimeler: C-sınıfı Uçucu Kül, Sülfürlü Atık, Tek Eksenli Basınç Dayanımı, Mikroyapı, Çimentolu Macun Dolgu

\begin{abstract}
In this study, the effect of Class-C Fly ash (FA) as partial replacement (5-15\% by weight) to sulphide tailings on the strength and microstructure properties of cemented paste backfill (CPB) was examined. Within this scope, CPB samples of control were prepared at $8.5 \mathrm{wt}$.\% binder dosage while the other samples containing FA were prepared at $7.5 \mathrm{wt} . \%$ binder dosage. These samples were subjected to uniaxial compressive strength (UCS) and porosity (MIP) tests. Findings revealed that all CPB samples containing FA produced notably higher (1.18-3.16 fold) UCSs than control samples. All CPB samples ensured the stability criterion for backfill material (UCS $\geq 1.0 \mathrm{MPa}$ ), whilst, only the CPB samples containing $15 \mathrm{wt}$ \% FA exceeded the roof (ground) support criterion (UCS $\geq 5.0 \mathrm{MPa}$ ). When the developments of porosity (MIP) were investigated, the partial replacement of sulphide tailings with FA enhanced the microstructure properties of CPB samples. These results suggest that the utilization of Class-C Fly ash (FA) as partial replacement to sulphide tailings is highly beneficial for the improvement of the strength, durability and microstructure properties of CPB.
\end{abstract}

Keywords: Class-C Fly Ash, Sulphide Tailings, Uniaxial Compressive Strength, Microstructure, Cemented Paste Backfill 
DEÜ FMD 21(61), 15-23, 2019

\section{Giriş}

Macun dolgu, madencilik faaliyetleri sonucu açığa çıkan cevher zenginleştirme atıklarının bir miktar çimento (\%2-10) ve su ile karıștırılarak yeraltı üretim boşluklarına depolanması işlemidir. Cevher zenginleștirme atıklarının yaklaşık \%50-55'inin yeraltı üretim boşluklarına güvenli bir şekilde depolanmasına olanak sağlayan macun dolgu, Avrupa Birliği tarafından da kabul edilmiş, en uygun atık yönetimi yöntemlerinden birisi olarak değerlendirilmektedir [1]. Atık yönetimi maliyetlerini azaltması, proses suyunun geri kazanımına imkan sağlaması, sülfürlü atıkların nötralizasyon potansiyelini arttırması, geçirgenliği düşük (>10-7m/sn) çimentolu (alkali) bir ortam içerisinde emniyetli bir şekilde depolanmasını sağlaması ve bunlara bağlı olarak atıkların yeraltı suyu ve havanın etkisine maruz kalmasını (asit maden drenajı olușumunu) büyük ölçüde engellemesi/yavaşlatması gibi çevresel, teknik ve ekonomik avantajlarından dolayı macun dolgu yöntemi, Kanada ve Avustralya bașta olmak üzere Dünyada 150'den fazla maden ișletmesinde kullanılmaktadır. Çayeli Bakır İşletmeleri'nde 1999'dan beri başarılı bir şekilde uygulanmasının sonucu olarak macun dolgu teknolojisi ülkemizde de yaygınlaşmaya ve son yıllarda Kastamonu Küre bakır ve İzmir Efemçukuru altın madeni işletmelerinde de uygulanmaya başlanmıştır [2].

Yeraltı madenciliğinde macun dolgu uygulamasının en önemli başarı kriterleri başlıca; i) belirli bir kür süresinde istenen dayanım kazanımını elde etmesi, ii) fiziksel ve kimyasal etkilere karşı duraylılığını koruyarak dayanım kaybına uğramaması, iii) borularda herhangi bir tıkanıklığa yol açmadan yeraltı üretim boşluklarına nakledilebilmesi, iv) işletme maliyetlerinin düşük olması ve v) yeraltı su kalitesine etki etmemesidir. Ancak macun dolgunun hazırlanmasında sülfür içeriği yüksek atık kullanılması durumunda uzun dönemde bazı duraylılık (dayanım kaybı) problemleriyle karşılaşılabilmektedir. Atık içerisinde bulunan sülfürlü mineraller (pirit vb.) su ve oksijen varlığında oksidasyona uğrayarak asit ve sülfat oluşumuna yol açmakta, açığa çıkan asit $(\mathrm{pH}$ 7'nin altında) çimento hidratasyon ürünlerinin çözünmesine ve bağlayı jellerinin zayıflamasına yol açmak suretiyle dolgu dayanımının düșmesine ve ağır metal salınımına neden olabilmektedir. Ouellet vd. [3] macun dolguya ilave edilen çimentonun baziklik sağlayarak yeraltında asit maden drenajı (AMD) oluşumunu ve ağır metal salınımını engellediğini/azalttığını ve dolgu içerisine oksijen difüzyonunu azaltarak sülfürlü minerallerin reaktivitesine bağlı asit ve sülfat oluşumunu sınırlandırdığını belirtmiștir. Ancak bazı araștırmacılar [4-8] macun dolguya ilave edilen çimentonun özellikle uzun dönemde sülfürlü minerallerin reaktivitesi sonucu oluşan asidin olumsuz etkisini elimine etmede yetersiz kaldığını saptamışlardır. Cihangir vd. [6] yapmış oldukları çalışmada \%5 oranında normal Portland çimentosu içeren macun dolgu numunelerinde 360 günlük kür süresi sonunda $\mathrm{pH}$ değerinin 6'nın altına düștüğünü ve oksidasyonun çimento içeren numunenin iç kısmına doğru ilerlediğini, buna karşın \%6-7 oranında çimento içeren numunelerde $\mathrm{pH}$ değerinin 9'un üzerinde kaldığını gözlemlemişlerdir. Tarig ve Nehdi [5] sülfürlü atıklardan (\%52,3 pirit içeriğine sahip) hazırladığı çimentolu macun dolgu numunelerinin $\mathrm{pH}$ değerinin 12'den 360 günlük kür süresi sonunda 4'lere kadar düștüğünü, bu tür atıklara karşı dirençli sülfata dayanıklı çimento kullanımında dahi pH'ın 6'lara kadar azaldığını belirtmiș ve macun dolguda yüksek sülfür içeriğine sahip atıkların nötralizasyonunda çimentonun tek bașına yeterli olmadığını ifade etmiștir. Zheng vd. [9] çimento miktarındaki artışın sülfürlü atıklardan hazırlanan macun dolguda dayanım kaybını engelleyemediğini, ancak dayanım kayıplarının bașlama süresini geciktirdiğini belirtmiș, dayanım kaybını engellemek için de puzolanik özelliğe sahip mineral katkı kullanımını önermiștir. Buna karşın Yin vd. [8] ise sülfür içeriğinin artmasıyla birlikte genleşme oranının arttığını, bunu engellemek için çimento miktarının \%8'den \%16'ya çıkartılmasının bile sülfür içeriği yüksek atıklardan hazırlanan macun dolguda çatlakların oluşmasını ve dayanım kaybını engelleyemediğini ortaya koymuştur. Bununla birlikte bağlayıcı maliyeti macun dolgu işletme maliyetlerinin \%50-75'ini teşkil ettiğinden çimento sarfiyatındaki artış, dolgu işletme maliyetlerini de olumsuz yönde etkileyecektir.

Son yıllarda yapılan bazı çalıșmalarda $\mathrm{CaO}$, $\mathrm{Ca}(\mathrm{OH})_{2}, \mathrm{CaCO}_{3}$ ve $\left(\mathrm{CaMg}\left(\mathrm{CO}_{3}\right)_{2}\right)$ gibi $\mathrm{Ca}$ içeriği yüksek endüstriyel artıkların (C sınıfı uçucu kül, mermer artığı vb.) sülfürlü atıkların/toprakların nötralizasyonunun sağlanmasında ve çevreye zararlı ağır metal salınımının engellenmesinde etkili olduğunu belirtilmektedir [7,10-12]. 
DEÜ FMD 21(61), 15-23, 2019

Tozsin vd. [11] mermer artığı içeren asidik toprak numunelerinin pH'ının 75 günlük bekletilme süresi boyunca 4,71'den 6,0'ya hızla arttığını, daha fazla miktarda mermer artığı ilavesinin $\mathrm{pH}^{\prime} ı$ daha hızlı bir şekilde yükselttiğini, buna karşın kontrol numunelerinin pH'ının aynı kür süresinde sabit $(4,71 \pm 0,18)$ kaldığını belirtmişlerdir. Erçıkdı vd. [12] çimentoya \%1030 oranında ikame olarak $\mathrm{CaO}$ içeriği yüksek uçucu kül kullanımının sülfürlü atıklardan hazırlanan macun dolguda yeterli dayanım kazanımı sağlamamasına karşın uzun dönemde dayanım kaybını engellediğini belirtmiștir. Benzer şekilde Erçıkdı vd. [7] puzolanik özelliği bulunmamasına karşın ögütülmüş mermer artığının sülfürlü atıklardan hazırlanan macun dolguda çimentoya ilave olarak \%10-30 oranında kullanımının $\mathrm{pH}$ ve dayanım artışı sağladığını belirtmiștir. Bu anlamda $\mathrm{CaO}$ içeriği yüksek C-sınıfı uçucu kül kullanımının sülfürlü atıkların nötralizasyonunda etkili olabileceği ve uzun dönemde macun dolguda olușabilecek dayanım kaybını engelleyebileceği düșünülmektedir.

Uçucu küller kömürün yakılarak elektrik üretildiği termik santrallerde, kömürün içindeki inorganik maddelerin firın ortamında erimesi ve bacadan atılması esnasında soğuyarak atmosfere karıșmadan önce elektrofiltreler vasitasıyla tutulan yan üründür [13]. Kömürün yanma tipinden kaynaklanan kimyasal kompozisyonuna bağlı olarak ASTM C618-17a [14]'ya göre $\mathrm{F}$ ve $\mathrm{C}$ sınıfı olmak üzere iki sınıfı vardır. F-sınıfı küller $\mathrm{SiO}_{2}+\mathrm{Al}_{2} \mathrm{O}_{3}+\mathrm{Fe}_{2} \mathrm{O}_{3} \geq \% 70$ olan antrasit veya bitümlü kömürün yakılmasıyla, C-sınıfı küller ise, $\mathrm{SiO}_{2}+\mathrm{Al}_{2} \mathrm{O}_{3}+\mathrm{Fe}_{2} \mathrm{O}_{3} \geq \% 50$ olan düşük bitümlü kömürün yakılmasıyla üretilmektedir. $\mathrm{CaO}$ içeriği \%10'dan fazla olduğu için yüksek kireçli uçucu kül olarak da adlandırılan C-sınıfı küller; düşük puzolanik özelliğinin yanı sıra kısmen bağlayıcılık özellik de göstermektedir $[10,13]$. Ülkemizde yıllık yaklaşık 18 milyon ton UK üretilmektedir. Bu çalışmada çimentolu macun dolgunun hazırlanmasında sülfür içeriği yüksek atık yerine ikame olarak ağırlıkça $\% 5, \% 10$ ve \%15 oranlarında C-sınıfı UK kullanımının 7-360 günlük kür süresi aralığında dolgunun dayanım kazanımına/kaybına ve mikroyapısına etkisi incelenmiştir. Elde edilen sonuçlar değerlendirilerek uçucu kül kullanımının faydaları tartışılmıştır.

\section{Materyal ve Metot 2.1. Atık malzeme}

Deneysel çalışmalarda kullanılan atık malzeme Etibakır Kastamonu-Küre İşletmesi cevher hazırlama tesisi çıkıșından alınmıș ve $500 \mathrm{~kg}$ kapasiteli varillere doldurularak Macun Dolgu Laboratuvarına getirilmiştir. Malvern Mastersizer ile yapılan tane boyut dağılımı analizinden $20 \mu \mathrm{m}$ altı malzeme miktarı ağırlıkça $\% 48,41$ olarak belirlenmiș (Șekil 1) olup, atık malzeme bu haliyle orta boyutlu macun dolgu malzemesi sınıfına girmektedir. Atığın ayrıca $4440 \mathrm{~cm}^{2} / \mathrm{g}$ özgül yüzey alanına sahip olduğu belirlenmiştir (Tablo 1).

Atığın spektrofotometre ve atomik adsorbsiyon spektrometre (AAS) yöntemleri ile belirlenen kimyasal özelliklerine göre ana bileșen olarak demir (III) oksit $\left(\mathrm{Fe}_{2} \mathrm{O}_{3}\right)$ ve silisyum dioksit $\left(\mathrm{SiO}_{2}\right)$ içerdiği tespit edilmiştir. Mineralojik bileşimlerinin belirlenmesi için yapılan X-ışınları difraktometre (XRD) analizlerinden atığın baskın olarak pirit $\left(\mathrm{FeS}_{2}\right)$ minerali içerdiği, ayrıca az miktarda kuvars, muskovit, albit, klorit gibi silikat grubu minerallerinin bulunduğu belirlenmiștir. Atığın detaylı fiziksel, kimyasal ve mineralojik özellikleri Tablo 1'de verilmiștir.

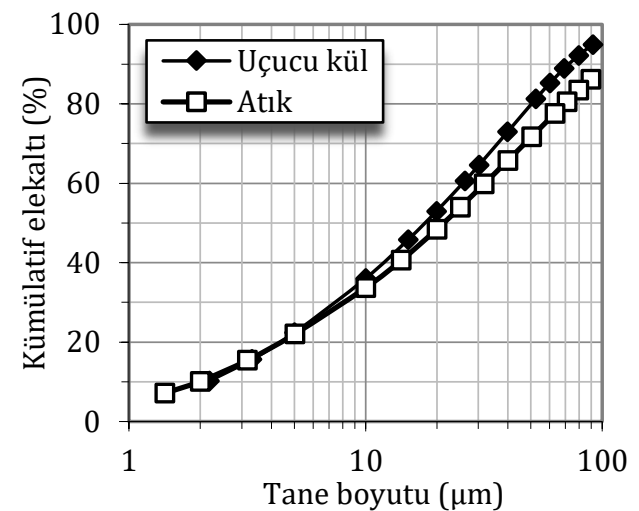

Şekil 1. Atık malzeme ve uçucu külün tane boyut dağılımları

\subsection{Bağlayıcı ve uçucu kül}

Deneysel çalışmalarda bağlayıcı olarak; Aşkale Çimento Sanayii A.Ş. Trabzon Çimento Fabrikası'ndan temin edilen Portland çimentosu (CEM I 42,5R) kullanılmıștır. Deneysel çalışmalarda kullanılan bağlayıcı malzemeye ait fiziksel, kimyasal ve mineralojik özellikler Tablo 1 'de verilmiştir.

Macun dolgu karıșımı içerisinde sülfürce zengin atığa ikame olarak kullanılan uçucu kül; 
DEÜ FMD 21(61), 15-23, 2019

Kahramanmaras Afșin Elbistan termik santralinden temin edilmiștir. UK, öğütme işleminden önce içerisinde bulunan doğal neminin uzaklaştırılması için etüvde yaklașık $50^{\circ} \mathrm{C}$ sicaklıkta kurutulmuştur. Kurutma işleminden sonra $105 \mathrm{dk}$ boyunca bilyalı değirmende kuru öğütmeye tabi tutulmuştur. Öğ̈̈tme sonucunda UK'nın $20 \mu \mathrm{m}$ altı malzeme miktarı \%53 olarak ölçülmüș olup, atığın tane boyut dağılımına oldukça yakın seviyededir (Şekil 1). Uçucu külün özgül yüzey alanı 6360 $\mathrm{cm}^{2} / \mathrm{g}$ olarak ölçülmüștür. AAS yöntemiyle belirlenmiș olan UK'nın kimyasal bileșimi Tablo 1 'de verilmiștir. UK'nın kimyasal bileşimine bakıldığında $\mathrm{CaO}$ içeriğinin oldukça yüksek $(\% 30,6)$ olması nedeniyle C-sınıfı uçucu kül sınıfına girmektedir. Ayrıca XRD cihazı kullanılarak elde edilen mineralojik bileșimi incelendiğinde kuvars, portlandit, anhidrat ve kalsit minerallerini içerdiği tespit edilmiștir (Tablo 1).

Tablo 1. Atık, bağlayıcı ve uçucu külün fiziksel, kimyasal ve mineralojik özellikleri

\begin{tabular}{|c|c|c|c|}
\hline Özellikler & Atık (\%) & Uçucu Kül (\%) & CEM I 42,5R (\%) \\
\hline \multicolumn{4}{|l|}{ Kimyasal bileșim } \\
\hline $\mathrm{SiO}_{2}$ & 31,68 & 34,96 & 20,57 \\
\hline $\mathrm{Al}_{2} \mathrm{O}_{3}$ & 9,13 & 13,92 & 4,81 \\
\hline $\mathrm{Fe}_{2} \mathrm{O}_{3}$ & 33,06 & 6,42 & 3,67 \\
\hline MgO & 3,99 & 2,32 & 1,35 \\
\hline $\mathrm{SO}_{3}$ & - & - & 2,97 \\
\hline $\mathrm{CaO}$ & 3,50 & 30,62 & 65,27 \\
\hline Serbest $\mathrm{CaO}$ & - & 8,67 & 1,19 \\
\hline Kızdırma kaybı & 16,0 & 3,4 & 2,1 \\
\hline Toplam & 99,33 & 94,16 & 99,90 \\
\hline Sülfür içeriği (S-2) (\%) & 15,82 & - & - \\
\hline Pirit içeriği $\left(\mathrm{FeS}_{2}\right)(\%)$ & 29,66 & - & - \\
\hline \multicolumn{4}{|l|}{ Fiziksel özellikler } \\
\hline Özgül ağırlık & 3,37 & 2,42 & 3,14 \\
\hline Özgül yüzey alanı $\left(\mathrm{cm}^{2} / \mathrm{g}\right)$ & 4440 & 6360 & - \\
\hline \multicolumn{4}{|l|}{ Mineralojik bileșim } \\
\hline & Pirit & Kuvars & $\mathrm{C}_{3} \mathrm{~S}: 58.44$ \\
\hline & Kuvars & Portlandit & $\mathrm{C}_{2} \mathrm{~S}: 14,95$ \\
\hline & Albit & Anhidrat & $\mathrm{C}_{3} \mathrm{~A}: 6,54$ \\
\hline & $\begin{array}{l}\text { Kalsit } \\
\text { Klorit }\end{array}$ & Kalsit & $\mathrm{C}_{4} \mathrm{AF}: 11,16$ \\
\hline
\end{tabular}

\subsection{Numunelerin hazırlanması}

Tablo 2'de detaylı olarak verilen "deneysel çalıșma koșulları" çizelgesine uygun olarak atık malzeme, bağlayıcı malzeme, uçucu kül ve karıșım suyu kullanılarak macun dolgu karışımları hazırlanmıștır.

Kontrol numunelerinin hazırlanmasında sadece sülfürlü atık malzeme kullanılmıștır. UK içeren numunelerde ise sülfürlü atık malzeme yerine ağırlıkça \%5, \%10 ve \%15 oranlarında ikame olarak UK kullanılmıștır (Tablo 2).

Tablo 2. Numunelerin hazırlanmasında kullanılan deneysel çalışma koşulları

\begin{tabular}{|c|c|c|c|c|c|c|c|c|}
\hline \multirow{2}{*}{ Karışım tipi } & \multicolumn{2}{|c|}{ İkame oranı (\%) } & \multicolumn{2}{|c|}{ Katı oranı (\%) } & \multirow{2}{*}{ Bağlayıcı oranı (\%) } & \multicolumn{2}{|c|}{$\mathrm{Su} /$ çimento oranı (s/ç) } & \multirow{2}{*}{ Slamp $(\mathrm{cm})$} \\
\hline & Atık & UK & 8,5 & 7,5 & & 8,5 & 7,5 & \\
\hline Kontrol & 100 & 0 & 73,70 & - & 8,5 & 4,20 & - & \multirow{4}{*}{19,05} \\
\hline$\% 5 \mathrm{UK}$ & 95 & 5 & - & 72,87 & & - & 4.96 & \\
\hline$\% 10 \mathrm{UK}$ & 90 & 10 & - & 73,22 & 7,5 & - & 4,88 & \\
\hline$\% 15$ UK & 85 & 15 & - & 73,66 & & - & 4,77 & \\
\hline
\end{tabular}


DEÜ FMD 21(61), 15-23, 2019

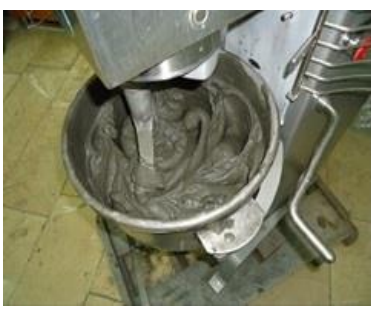

(a)

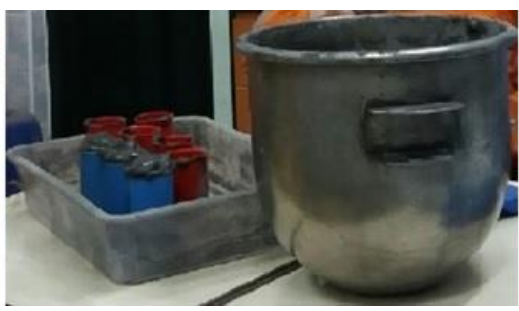

(b)

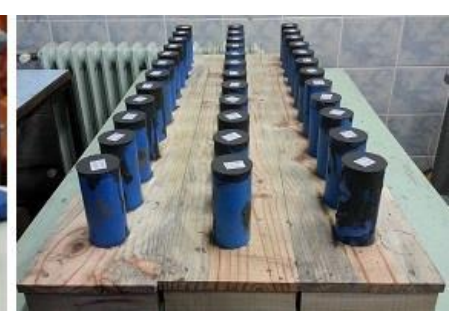

(c)

Şekil 2. Macun dolgu karışımında kullanılan mikser (a) karışımın kalıplara dökülmesi (b) ve macun dolgu örneklerinin drenaj işlemi (c)

Macun dolgu karışımlarının hazırlanmasında, bağlayıcı malzeme (çimento) katı oranına göre hesaplanarak ağırlıkça ilave edilmiştir. Macun dolgu karışımının istenen akışkanlığa (kıvama) gelmesi için karışım içerisine gerekli miktarda musluk suyu katılmıştır. Karışımın (atık malzeme, bağlayıcı, uçucu kül ve su) homojen bir şekilde hazırlanması için yapılan karıștırma işlemi 105 devir/dk'lık dönme hızında 7 dakika süreyle 20,8 lt kapasiteli Univex SRMF 20 model mikserde yapılmıştır (Şekil 2a). Hazırlanan macun dolgu karıșımı $5 \times 10 \mathrm{~cm}$ (çap x boy) boyutlarındaki drenajlı silindirik numune kalıplarına dökülmüş (Şekil 2b) ve numuneler, içerisinde bulunan fazlalık suyunun drene olması için 24 saat süre ile drenaj masalarında bekletilmiştir (Şekil 2c). Bu sürenin sonunda numuneler önceden belirlenen kür süreleri (7, $28,90,180$ ve 360 gün) boyunca açık şekilde yaklaşık \%80 nem ve $20^{\circ} \mathrm{C}$ sıcaklığa sahip kür dolabında kür işlemine tabi tutulmuştur.

\subsection{Basınç dayanımı testi}

Basınç dayanımı testine tabii tutulan toplam 60 adet silindirik macun dolgu numunesinin boy/çap oranı=2/1 olup, numunelerin alt ve üst yüzeyleri deney öncesi düzeltilmiştir. Numunelerin tek eksenli basınç dayanımı testi önceden belirlenen kür süreleri sonunda yük kapasitesi $50 \mathrm{kN}$ ve $1,00 \mathrm{~mm} / \mathrm{dk}^{\prime} \mathrm{l} \mathrm{k}$ bir yükleme hızına sahip UTEST marka bilgisayar kontrollü basınç ve deformasyon ünitesinde ASTM C39/C39M-16b [15] tarafından önerilmiş yönteme göre gerçekleştirilmiştir (Şekil 3). Her bir kür süresi için 3 adet numune test edilmiş ve sonuçlar bu numunelerden elde edilen değerlerin ortalaması olarak alınmıştır.

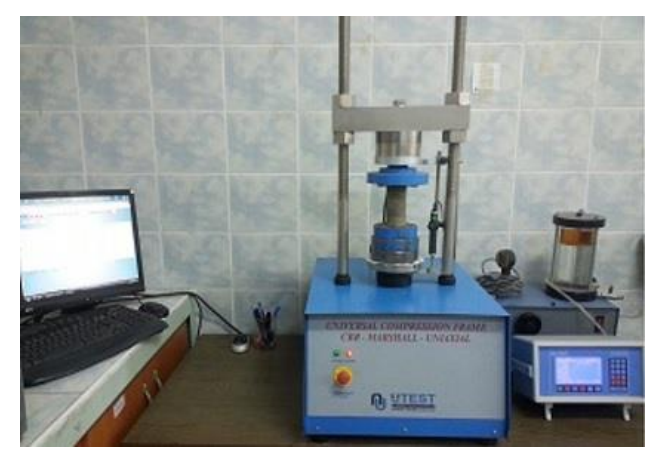

Şekil 3. Tek eksenli basınç dayanımı testi

\subsection{Porozite (MIP) testi}

Porozite (MIP) testi için ayrı olarak (tahribatsız) hazırlanan 3 adet numune 28 günlük kür süresi tamamlandığında ağırlıklarının sabitlenmesi için $50^{\circ}{ }^{\circ}$ 'de 36 saat süreyle etüvde kurutulmuș ve hemen ardından nemden etkilenmemesi için desikatöre konularak soğutulmuştur. Porozite testleri Micromeritics Autopore IV 9410 model civalı Porozimetre cihazı kullanılarak ASTM D 4404-10 [16] standardına göre gerçekleştirilmiştir (Şekil 4). Porozite analizleri sonucunda gözenek özellikleri, Uluslararası Kuramsal ve Uygulamalı Kimya Sınıflaması Birliği'nin [17] çimentolu malzemeler için önerdiği gözenek boyutu sinıflamasına göre değerlendirilmiştir.

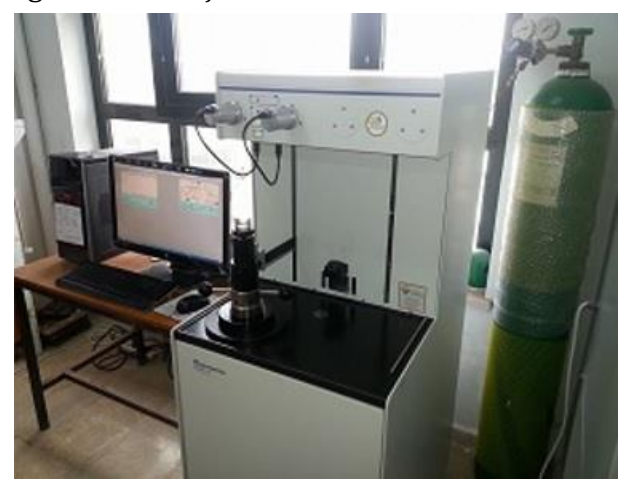

Şekil 4. Porozite (MIP) test cihazının görünümü 


\section{Bulgular ve Tartışma}

\subsection{Basınç dayanımının değerlendirilmesi}

Şekil 5, \%8,5 bağlayıcı oranında hazırlanmıș kontrol numuneleri ile \%7,5 bağlayıcı oranında hazırlanmış ve atık malzeme yerine ağırlıkça \%5, $\% 10$ ve $\% 15$ UK içeren numunelerin $7,28,90$, 180 ve 360 günlük kür süreleri sonundaki tek eksenli basınç dayanımı (TEBD) sonuçlarını göstermektedir.

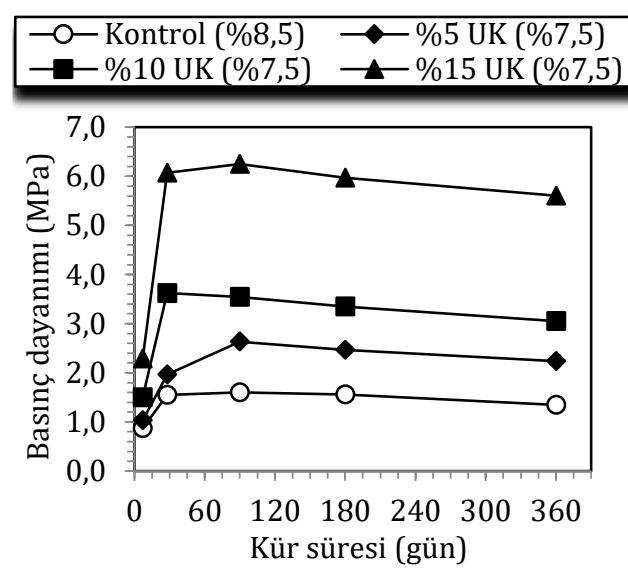

Şekil 5. Sülfürlü atık malzeme yerine C-sınıfı UK ikamesinin basınç dayanımına etkisi

Bütün macun dolgu numunelerinin basınç dayanımları, genel olarak 90 güne kadar artma eğilimi göstermiş, sonrasında düşüş eğilimi gözlenmiştir. Ayrıca UK içeren numunelerin basınç dayanımı, kür süresinden bağımsız olarak ikame oranının artmasıyla birlikte artmıştır. Atık malzemeye \%5-15 UK ikamesinin numunelerin basınç dayanımına katkısı incelendiğinde; UK içeren numunelerin tüm kür sürelerinde kontrol numunelerine kıyasla \%18-316 arasında daha yüksek basınç dayanımı ürettiği belirlenmiştir (Şekil 5). Kontrol numunelerinin hazırlanmasında $1 \mathrm{~m}^{3}$ dolgu için \%8,5 bağlayıcı oranında $130 \mathrm{~kg}$ çimento kullanılırken, \%5-15 UK içeren numunelerin hazırlanmasında \%7,5 bağlayıcı oranı için $110 \mathrm{~kg}$ bağlayıcı kullanılmıştır (Tablo 3). Üstelik atığa kıyasla daha yüksek özgül yüzey alanına sahip UK'nın atık yerine \%5-15 oranında ikame edilmesiyle dolgunun su/çimento oranı 4,20'den 4,774,96'lara çıkmış, katı oranı azalmıştır (Tablo 12). Wang ve Park [18] yüksek miktarda uçucu külün çimentolu malzemelerde kullanımının betonun su ihtiyacını azalttığını belirtmiștir. Ancak bu çalışmada atık yerine \%5-15 oranında UK ikamesi (74-223 kg), aynı akışkanlık için dolgunun su gereksinimini kısmen arttırmıștır
(Tablo 2). Daha düşük bağlayıcı içermesine ve daha yüksek su/çimento oranına rağmen UK içeren macun dolgu numunelerinin yüksek dayanım üretmesi; UK'nın puzolanik özelliği nedeniyle kalsiyum hidroksit $\left(\mathrm{Ca}(\mathrm{OH})_{2}\right)$ ile reaksiyona girerek bağlayıcılık özelliğine sahip ilave hidratasyon ürünü olan ikincil C-S-H jelleri üretmesi ve \%30,6 oranında $\mathrm{CaO}$ içermesi nedeniyle UK'nın kısmen bağlayıcılık özelliğinin de bulunmasıyla açıklanabilir [19]. Ayrıca, UK'nın atık malzemeye kıyasla nispeten daha ince tane boyutuna ve amorf yapisına sahip olmasından dolayı atık taneleri arasındaki boşlukları doldurması ve böylelikle büyük boyutlu gözeneklerin küçülmesi ile ilişkilendirilebilir [19,20]. Türker vd. [13] AfşinElbistan uçucu küllerinin erken kür sürelerinde puzolanik özelliğinin nispeten düşük olduğunu, 90 gün ve sonrasında daha etkili olduğunu belirtmiştir. Ancak Şekil 5 incelendiğinde, Csınıfı UK içeren numunelerin 7 ile 28 günlük kür süreleri arasındaki dayanım kazanımındaki artışın \%91,5-165 oranında olduğu, buna karşın 28-90 günlük kür süresinde ise artışın \%2,9-33,6 oranında kaldığı gözlenmiştir.

Pratikte, maden operatörlerinin yeraltında güvenli bir şekilde çalışabilmesi ve üretim yapılan bölge etrafındaki dolgunun duraylılığını koruyabilmesi için 28-360 günlük kür süresi sonunda macun dolgunun en az 1,0MPa dayanıma [21], tavan (zemin) tahkimatı olarak kullanılabilmesi için aynı kür sürelerinde en az $5,0 \mathrm{MPa}$ dayanıma sahip olması gerekmektedir [22]. Bu kriterler göz önüne alındığında, tüm macun dolgu karışımları cevheri alınmış boşluklarda dolgu olarak kullanılabilecek potansiyele sahipken, tavan tahkimatı olarak ise sadece \%15 UK ikameli dolgu karışımlarının (28 ve 360 günde sırasıyla $6,07-5,60 \mathrm{MPa} \geq 5,0 \mathrm{MPa}$ ) kullanılabileceği görülmektedir (Şekil 5). Dayanım kaybı açısından değerlendirildiğinde 90-360 günlük kür süresi aralığında kontrol numunelerinde yaklaşık \%16 oranında dayanım kaybı oluşmuş, buna karşın \%15 UK içeren numunelerde bu oran \%10'a düșmüștür (Tablo 3). Macun dolgu numunelerinde düşük seviyelerde dayanım kaybı oluşmasına rağmen, 360 günlük kür süresi sonunda tüm numunelerin dayanımı istenen seviyenin $(T E B D \geq 1,0 \mathrm{MPa})$ üzerinde kalmıştır. Ayrıca sülfürlü atığa UK ikamesinin bağlayıcı tasarrufunda yaklaşık \%15 oranında azalma sağladığı, böylece dolgu işletme maliyetlerinde ögütme ișlemi nedeniyle oluşabilecek artışın elimine edilebileceği anlaşılmıștır. 
DEÜ FMD 21(61), 15-23, 2019

Tablo 3. $1 \mathrm{~m}^{3}$ dolgu karıșımında kullanılan bağlayıcı/UK miktarları ve dolgunun bazı özellikleri

\begin{tabular}{lllll}
\hline \multirow{2}{*}{ Özellikler } & \multicolumn{3}{c}{ Karışım tipi } \\
\cline { 2 - 4 } & Kontrol & \%5 UK & \%10 UK & \%15 UK \\
\hline Katı oranı (\%) & 73,70 & 72,87 & 73,22 & 73,66 \\
Akışkanlık (cm) & 19,05 & & & 2,020 \\
Birim hacim ağırlık (ton/m³) & 2,070 & 2,030 & 2,024 & 10,32 \\
90-360 gün dayanım kaybı (\%) & 15,92 & 15,16 & 13,90 & 7,5 \\
Bağlayıcı oranı (\%) & 8,5 & 7,5 & 7,5 & 110,59 \\
Bağlayıcı miktarı (kg) & 130,0 & 110,94 & 111,50 & 223,19 \\
Uçucu kül miktarı (kg) & - & 73,96 & 148,20 & 14,16 \\
Bağlayıcı tasarrufu (\%) & - & 14,66 & 14,23 & \\
\hline
\end{tabular}

\subsection{Porozite sonuçlarının değerlendirilmesi}

Porozite (MIP) analizi harç, beton ve macun dolgu gibi çimentolu malzemelerin toplam porozite (gözeneklilik) ve gözenek tane boyut dağılımlarının değerlendirilmesinde yaygın bir şekilde kullanılmaktadır. Bu amaçla, \%8,5 bağlayıcı oranında hazırlanan kontrol numunesi ve sülfürlü atık yerine ikame olarak \%5-15 oranında UK kullanılarak \%7,5 bağlayıcı oranında hazırlanan numunelerin 28 günlük kür süresi sonundaki toplam ve kademeli porozite sonuçları Şekil 6'da verilmiştir.
Atık malzemeye $\% 5$ ve $\% 15$ UK ikamesi ile birlikte dolgu numunelerinin toplam porozite ( $\left.n_{\text {top}}\right)$ değerleri kontrol numunesine kiyasla sırasıyla \%3,0 ve $\% 8,0$ azalmıştır. (Şekil 6 a ve Tablo 4). UK içeren numunelerin kontrol numunesine kıyasla düșük poroziteye sahip olması, UK'nın düşük puzolanik özelliği ve bağlayıcı özelliğinin sayesinde ilave hidratasyon ürünlerinin (C-S-H jelleri) oluşması ile nispeten iri atık tanelerinin arasındaki boşlukların doldurulmasıyla açıklanabilir [19].

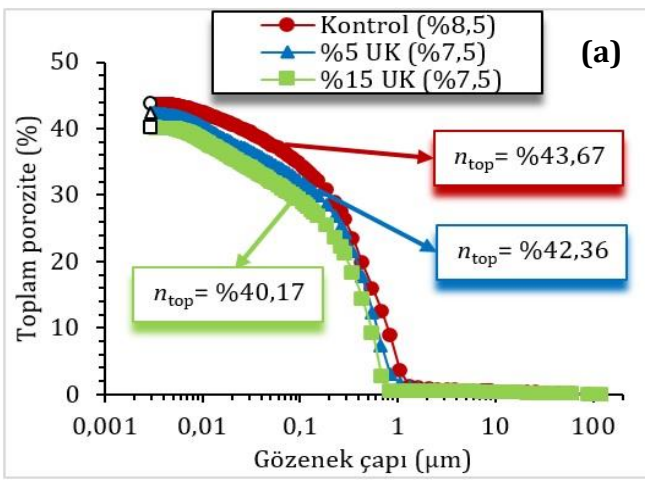

Şekil 6. Macun dolgu numunelerinin 28 gündeki toplam (a) ve kademeli (b) porozite sonuçları

Ceșitli araștırmacılar çimentolu malzemelerin porozite (gözenek) gelişimini incelemek için gözenek boyut dağılımını gözenek çapları açısından farklı biçimlerde kategorize etmişlerdir $[3,23,24]$. Bu çalışmada, gözenek boyut dağılımı; büyük boyutlu porozite $(>0,05$ $\mu \mathrm{m})$ ve orta boyutlu porozite $(0,002-0,05 \mu \mathrm{m})$ olarak sınıflandırılmıș ve diğer parametrelerle birlikte Tablo 4'te açıklanmıştır. Toplam poroziteyi olușturan büyük boyutlu ve orta boyutlu porozite değerleri incelendiğinde, UK ikamesi ile birlikte büyük boyutlu porozite miktarı azalmıș, orta boyutlu porozite miktarı ise artmıştır (Şekil 6b). Özellikle \%15 UK içeren numunelerin $n_{\text {top }}$ değerlerinin kontrol numunesine kıyasla daha düşük çıkması; UK'nın

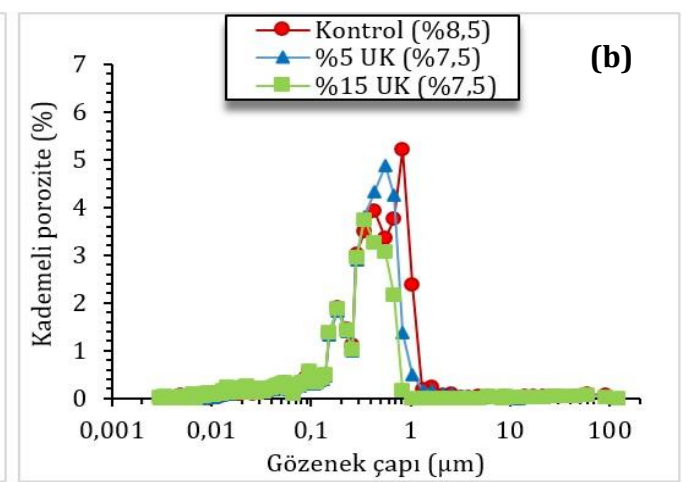

filler etkisi sayesinde büyük boyutlu gözeneklerin kapanması veya küçülerek orta boyutlu gözeneğe dönüşmesi ile ilişkilendirilmiştir [19,20] (Tablo 4). Porozite testleri sonucunda elde edilen veriler yardımıyla belirlenen $d_{\text {eș }}$ (eşik gözenek çapı) ve kademeli porozite değerlerinin diğer parametrelerle uyumlu olarak UK ikame miktarının artmasıyla birlikte sırasıyla yaklaşık \%58 ve $\% 28$ oranında azaldığı tespit edilmiștir. (Şekil $6 \mathrm{~b}$ ve Tablo 4). Sülfürlü atık yerine \%5-15 oranında C sınıfı UK ikamesi durumunda dolgu numunelerinde gözlenen dayanım ve duraylılık özelliklerindeki iyileşmenin aynı zamanda mikroyapı özellikleri ile de ilișkili olduğu anlaşılmıștır. 
DEÜ FMD 21(61), 15-23, 2019

Tablo 4. Porozite (MIP) testine ait teknik parametreler

\begin{tabular}{|c|c|c|c|c|c|c|}
\hline \multirow[b]{2}{*}{ Karışım Tipi } & \multirow[b]{2}{*}{$\begin{array}{l}\text { Kür Süresi } \\
\text { (gün) }\end{array}$} & \multicolumn{3}{|c|}{ Toplam Porozite $\left(n_{\text {top }} ; \%\right)$} & \multirow[b]{2}{*}{$\begin{array}{l}\text { (c)Eşik Gözenek } \\
\text { Çapı }\left(d_{\text {eș; }} ; \mu \mathrm{m}\right)\end{array}$} & \multirow[b]{2}{*}{$\begin{array}{l}\text { Kademeli } \\
\text { Porozite (\%) }\end{array}$} \\
\hline & & $n_{\text {top }}$ & $\begin{array}{l}\text { (a) Orta Boyutlu } \\
\text { Porozite }\end{array}$ & $\begin{array}{l}\text { (b)Büyük Boyutlu } \\
\text { Porozite }\end{array}$ & & \\
\hline Kontrol $(\% 8,5)$ & \multirow{3}{*}{28} & 43,67 & 6,078 & 37,592 & 0,836 & 5,21 \\
\hline$\% 5$ UK $(\% 7,5)$ & & 42,36 & 7,621 & 34,739 & 0,554 & 4,86 \\
\hline$\% 15$ UK $(\% 7,5)$ & & 40,17 & 8,146 & 32,024 & 0,350 & 3,75 \\
\hline
\end{tabular}

(a) Orta boyutlu gözenek: 0,002-0,05 $\mu \mathrm{m}$ arasındaki gözeneklerin gözeneklilik değeri

(b)Büyük boyutlu gözenek: 0,05 $\mu$ m'den büyük gözeneklere ait gözeneklilik değeri

(c) Eşik gözenek çapı: Kademeli porozite eğrisinin en dik noktasına karşıllk gelen çap değeri $[17,23]$.

\section{Sonuçlar}

Bu çalışmada sülfürlü atık malzeme yerine ikame olarak \%5-15 oranında C-sınıfı uçucu kül kullanılarak \%7,5 bağlayıcı oranında hazırlanan ÇMD numuneleri için 7, 28, 90, 180 ve 360 gün sonunda tek eksenli basınç dayanımı ve 28 gün sonunda mikroyapı (MIP) testleri yapılmıştır. Elde edilen sonuçlar \%8,5 bağlayıcı oranında hazırlanan kontrol numunelerinin dayanım ve mikroyapı özellikleri ile karşılaștırılmış ve aşağıda özetlenmiștir.

i.Tüm ÇMD numunelerinin basınç dayanımı genel olarak 90 güne kadar artma, sonrasında ise azalma eğilimi göstermiștir. C-sınıfı UK içeren numuneler tüm kür sürelerinde kontrol numunelerine klyasla daha yüksek dayanım üretmiş ve karışımda UK miktarının artmasıyla dayanım kazanımı artmış, uzun dönemde dayanım kaybı azalmıștır. Ayrıca UK kullanımının çimento tüketiminde yaklaşık \%15 oranında azalma sağlayacağ anlaşılmıştır.

ii.Sülfürlü atık yerine ağırlıkça \%15 oranında UK ikame edilerek hazırlanan dolgunun oldukça yüksek dayanım (TEBD $\geq 5,0 \mathrm{MPa})$ üretmesi nedeniyle yeraltı üretim boşluklarında tahkimat malzemesi olarak kullanılabileceği anlaşılmıştır. Ayrıca diğer dolgu karışımlarının da (kontrol ve \%5 UK içeren) 28 ve 360 günde 1,0MPa'dan daha yüksek dayanım ürettiği ve bu nedenle yan üretim odalarının üretilmesi ve dolduruluncaya kadar geçen sürede bütünlüklerini koruyabileceği belirlenmiștir.

iii.Kontrol numunelerine klyasla UK kullanımının toplam porozite ( $\left.n_{\text {top }}\right)$, büyük boyutlu porozite $(>0,05 \mu \mathrm{m})$ miktarı, eşik gözenek çapı $\left(d_{\text {eş}}\right)$ ve kademeli porozite değerlerinde azalma, orta boyutlu porozite miktarında artış sağlayarak macun dolgu numunelerinin mikroyapısını iyileștirdiği, bunun da dolgunun dayanım ve duraylılık özelliklerine olumlu yönde katkı sağladığı anlaşılmıştır.
Sonuç olarak; sülfürlü atıklardan hazırlanan macun dolguda atığa ikame olarak C-sınıfı uçucu kül kullanımının, macun dolguda hem yüksek dayanım kazanımı ve duraylılık sağladığı hem de dolgunun mikroyapısını iyileştirdiği görülmüştür. Böylece dolgu içinde yer alan sülfürlü minerallerin reaktivitesi sonucu oluşabilecek AMD ve ağır metal salınımını engelleyerek veya azaltarak çevreye duyarlı madencilik faaliyetlerinin sürdürülmesine katkı sağlayacağı, bunun için de ilave deneysel çalışmalara (statik/kinetik testler vb.) gereksinim olduğu anlașılmıștır. Ayrıca yeraltı üretim boşluklarının doldurulmasında yüksek hacimlerde UK kullanılması, söz konusu UK'nın yerüstünde depolanması sonucu oluşabilecek problemlerin (toz, görüntü kirliliği vb.) elimine edilmesini ve depolama için ihtiyaç duyulan geniş alan gereksinimini azaltacaktır. Bununla birlikte C-sınıfı uçucu küllerin sülfürlü atık yerine belirli oranlarda kullanılarak yeraltında depolanmasına yönelik henüz endüstriyel uygulama bulunmadığından teknik ve ekonomik açıdan değerlendirmeye ihtiyaç bulunmaktadır.

\section{Teşekkür}

$\mathrm{Bu}$ çalışma FDK 2016-5500 No'lu Karadeniz Teknik Üniversitesi Bilimsel Araştırma Projesi tarafından desteklenmiştir.

\section{Kaynakça}

[1] European Commission, 2009. Reference document on best available techniques for management of tailings and waste-rock in mining activities, s. 427435.

[2] Erçıkdı, B., Cihangir, F., Kesimal, A., Deveci, H., Eğriboyunoğlu, M., Yılmaz, K. 2017. Macun Dolgunun Çevresel Etkileri: ÇBİ Deneyimi. Uluslararası Madencilik Ve Çevre Sempozyumu (ISME 2017), 2729 Eylül, Bodrum/Muğla, 359-375.

[3] Ouellet, S., Bussière, B., Aubertin, M., Benzaazoua, M. 2007. Microstructural evolution of cemented paste backfill: Mercury intrusion porosimetry test results. Cement and Concrete Research, Cilt. 37, No. 12, s. 1654-1665. DOI: 10.1016/j.cemconres.2007.08.016

[4] Bertrand, V.J., Monroy, M.G., Lawrence, R.W., 2000. Weathering characteristics of cemented paste 
DEÜ FMD 21(61), 15-23, 2019

backfill: mineralogy and solid phase chemistry. In Proceedings from the 5 th international conference on acid rock drainage, 863-876.

[5] Tariq, A., Nehdi, M. 2007. Developing durable paste backfill from sulphidic tailings. Waste and Resource Management, Cilt. 160 , No. 4, s. $155-166$. DOI 10.1680/warm.2007.160.4.155

[6] Cihangir, F., Ercikdi, B., Kesimal, A., Turan, A., Deveci, H. 2012. Utilisation of alkali-activated blast furnace slag in paste backfill of high-sulphide mill tailings effect of binder type and dosage. Minerals Engineering, Cilt. 30, s. 33-43. DOI 10.1016/j.mineng.2012.01.009

[7] Ercikdi, B., Külekci, G., Yılmaz, T. 2015. Utilization of granulated marble wastes and waste bricks as mineral admixture in cemented paste backfill of sulphide-rich tailings. Construction and Building Materials, Cilt. 93, s. 573-583. DOI 10.1016/j.conbuildmat.2015.06.042

[8] Yin, S., Shao, Y., Wu, A., Wang, Y., Chen, X. 2018 Expansion and strength properties of cemented backfill using sulphidic mill tailings. Construction and Building Materials, Cilt. 165, s. 138-148. DOI: 10.1016/j.conbuildmat.2018.01.005

[9] Zheng, J., Guo, L., Sun, X., Li, W., Jia, Q. 2018. Study on the strength development of cemented backfill body from lead-zinc mine tailings with sulphide. Advances in Materials Science and Engineering, DOI: 10.1155/2018/7278014 (In Press)

[10] Xenidis, A., Mylona, E., Paspaliaris, I. 2002. Potential use of lignite fly ash for the control of acid generation from sulphidic wastes. Waste Management, Cilt. 22 No. 6, s. 631-641. DOI: 10.1016/S0956 053X(01)00053-8

[11] Tozsin, G., Arol, A.I., Oztas, T., Kalkan, E. 2014. Using marble wastes as a soil amendment for acidic soil neutralization. Journal of environmental management, Cilt. 133 , s. 374-377. DOI: 10.1016/j.jenvman.2013.12.022

[12] Ercikdi, B., Cihangir, F., Kesimal, A., Deveci, H., Alp, I. 2009. Utilization of industrial waste products as pozzolanic material in cemented paste backfill of high sulphide mill tailings. Journal of hazardous materials, Cilt. 168 , No. $2-3$, s. $848-856$. DOI: 10.1016/j.jhazmat.2009.02.100

[13] Türker, $P$., Erdoğan, $B$, Katnas, F., Yeğinoball, A 2009. Türkiye'deki Uçucu Küllerin Sinıflandırılması ve Özellikleri. Türkiye Çimento Müstahsilleri Birliğ (TCCMB), AR-GE Enstitüsü, Ankara, s. 114.

[14] ASTM C618-17a, 2017. Standard Specification for Coal Fly Ash and Raw or Calcined Natural Pozzolan for Use in Concrete. Annual Book of ASTM Standards, ASTM International, West Conshohocken, PA.

[15] ASTM C39/C39M-16b, 2016. Standard Test Method for Compressive Strength of Cylindrical Concrete Specimens, Annual Book of ASTM Standards, ASTM International, West Conshohocken, PA.

[16] ASTM D4404-10, 2010. Standard Test Method for Determination of Pore Volume and Pore Volume Distribution of Soil and Rock by Mercury Intrusion Porosimetry, Annual Book of ASTM Standards, American Society of Testing Material.

[17] IUPAC, 1972. Manual of Symbols and Terminology. Appendix 2-Part 1: Colloid and Surface Chemistry, Journal of Pure and Applied Chemistry. Cilt. 31, s. 578-593. DOI: 10.1351/pac197231040577

[18] Wang, X.Y., Park, K.B. 2015. Analysis of compressive strength development of concrete containing high volume fly ash. Construction and Building Materials, Cilt. 98, s. 810-819. DOI: 10.1016/j.conbuildmat.2015.08.099

[19] Memon, A.H., Radin, S.S., Zain, M.F.M., Trottier, J.F. 2002. Effects of mineral and chemical admixtures on high-strength concrete in seawater. Cement and Concrete Research, Cilt. 32, No. 3, s. 373-377. DOI: 10.1016/S0008-8846(01)00687-1

[20] Shaikh, F.U.A, Supit, S.W.M. 2015. Compressive strength and durability properties of high volume fly ash (HVFA) concretes containing ultrafine fly ash (UFFA). Construction and building materials, Cilt. 82, S. 192-205. DOI: 10.1016/j.conbuildmat.2015.02.068

[21] Yumlu, M. 2001. Backfill Practices at Cayeli Mine. 17th International Mining Congress and Exhibition of Turkey, 19-22 June, Ankara, 333-339.

[22] Belem, T., Benzaazoua, M. 2004. An overview on the use of paste backfill technology as a ground support method in cut-and-fill mines. 5th International Symposium on Ground support in Mining and Underground Construction, 28-30 September, PerthWestern Australia, 637-650.

[23] Yilmaz, E., Belem, T., Bussière, B., Benzaazoua, M. 2011. Relationships between microstructural properties and compressive strength of consolidated and unconsolidated cemented paste backfills. Cement and Concrete Composites, Cilt. 33, No. 6, s. 702-715. DOI: 10.1016/j.cemconcomp.2011.03.013

[24] Abdul-Hussain, N., Fall, M. 2011. Unsaturated hydraulic properties of cemented tailings backfill that contains sodium silicate. Engineering geology, Cilt. 123, No. 4, s. 288-301. DOI: 10.1016/j.enggeo.2011.07.011 